\title{
Materials Selection for Sustainable Executive Aircraft Interiors
}

\author{
Celise Villa dos Santos ${ }^{a *}$, Daniel Rodrigo Leiva ${ }^{a}$, Fábio Rodrigues Costa ${ }^{a}$, \\ José Angelo Rodrigues Gregolin ${ }^{a}$
}

\author{
${ }^{a}$ Departamento de Engenharia de Materiais, Núcleo de Informação Tecnológica em Materiais, \\ Universidade Federal de São Carlos - UFSCar, Km 235, Rod. Washington Luís, \\ CEP 13565-905, São Carlos, SP, Brazil
}

Received: May 19, 2015; Revised: October 28, 2015, 2015; Accepted: December 21, 2015

\begin{abstract}
This study proposes a methodological guide to explore and select materials for executive aircraft interiors, contributing toward a perspective of materials requirements, indicators and strategies to design more environmentally sustainable products. This was motivated by the signs from the aviation industry to reduce its environmental impact and the permanent need to push for cost efficiency. The guide includes a schedule framework of materials requirements for sustainable design, and also aeronautical materials and marketing requirements. It was prepared by mapping sustainability demands for materials selection during product development, supported by a case study. Patented eco-friendly materials solutions for the case study involving the aircraft furniture structural panels were described and analyzed, considering the materials requirements of the aeronautical project. Composites of bio-polymers reinforced with natural fibers, preferably with solid cores, seem to be the most promising solutions to substitute the current panels.
\end{abstract}

Keywords: Aircraft interiors, Materials selection, Environment, Sustainability

\section{Introduction}

The executive aircraft market is one of the most important segments of the Brazilian aeronautical industry, which is one of the four largest producers in the world ${ }^{1}$.

In the executive jet manufacturing industry, the question of sustainability is not sufficiently clear, especially with regard to interior components where materials play an important part in product differentiation. The initiatives to reduce the environmental impact of interior components are the result of government regulations and laws that restrict the materials used. The solutions of the materials used so far have partially solved the problem and the aircraft users hardly ever notice these changes. The procedures are limited to developing material solutions such as water based coatings, low-emission tanning leather, wood veneers from quickly renewable species and the use of natural fiber fabrics.

The executive jet industry has also implemented particular product design and manufacturing practices to minimize the use of environmental resources, with additional cost reduction gains. In this aeronautical segment the cost reduction pressures are due to the strong and growing competitiveness in a relatively small market. The executive aircraft manufacturers and consumer markets are currently concentrated in North America and Europe, but tend to migrate to emerging countries in Latin America, Asia, Middle East and Africa, which have emerging aeronautical industries ${ }^{1,2}$. The current manufacturers, which dominate materials and process technology, will face competition from

*e-mail: celise@nit.ufscar.br these new emerging players which also have technology and investment capacity.

It is in this scenario that the technological driving forces of the aviation industry will push for cost efficiency measures and for the reduction of environmental impacts ${ }^{1-4}$. Thus, greener interiors for executive aircrafts gain a competitive advantage as a possible marketing solution.

Most of the new materials currently developed and used to produce aircraft interiors have positive and negative impacts on sustainability and competitiveness. Balancing the properties of materials to simultaneously reach these aspects require better understanding the environmental issues of the material selection process in the product development.

The main decisions in materials selection are usually taken during the product design and have to meet the driving forces such as market demands, cost reduction, legal requirements and societal pressures for environmental sustainability $^{5-7}$. However, there is still a lack of specific studies concerning the subject of aircraft interiors, especially regarding the selection of materials and processes in the context of product development methodologies, as well as sustainability concerns.

The objective of this study is to propose a methodological guide for selecting materials during the development of executive aircraft interior components based on relevant ecodesign strategies and indicators, as well as the critical materials requirements. It is expected that the proposed guide favors an environmental sustainability design while maintaining compliance with marketing and aeronautical demands. 


\section{Literature review}

Materials selection activities are in almost all product development phases ${ }^{3,5-7}$, and concentrated in the preliminary ones in which the product concept is defined and its design is embodied and detailed. The environmental analysis of the product is usually applied during the phase of Embodiment and Detail of the design, which includes assessing the environmental impact and availability of raw materials, as illustrated in Figure 1. It also covers the final phases of product follow-up and product end-of-life to evaluate new materials requirements and executing the disposal plans. The main environmental analytical methodologies generally used are Life Cycle Assessment, Design for Environment, Ecodesign guides and materials selection tools such as Ashby Eco-Audits $^{8-13}$. The materials selection in these phases is supported by environmental indicators.

The materials selection decisions should include the materials sustainability indicators and also the sustainability indicators of economic and social dimensions, taking into account how they influence the product in all life cycle phases, as shown in Figure 2. A single eco-indicator can also be developed for each evaluated material combining all the observed environmental impacts, but it is a challenge due to the complex interferences of the materials used at local, regional and global levels. This normally results in strategies for materials selection that prioritize how the materials impact in only some phases of the product life cycle, for example, the energy consumption impacts and carbon footprint in the Ashby Eco-Audits analytical methodology ${ }^{8}$. Strategies based on Ashby Eco-Audits may not be enough to evaluate the materials selected for products that generally use non recyclable materials and possible toxic substances such as the actual aircraft interiors. Considering environmental issues, materials selection for aeronautical interiors must also include indicators related to how toxic substances impact humans and the environment, as well as the pollution caused by product disposal at the end of the life cycle ${ }^{14-16}$. These complex human safety and environmental issues have to meet chemical product restrictions ${ }^{17}$ and regulations for the disposal of products ${ }^{18-20}$.

Most of the ecodesign strategies usually chosen for product design directly affect the materials selected, as shown in Table 1. There is a positive relation between product sustainability improvements and manufacturing optimization practices focused on costs reduction, which are frequently limited by the materials initially chosen during product development ${ }^{4,21,22}$.

The leading commercial aircraft manufacturers have adopted ecodesign practices and guides that normally emphasize environmental conservation efforts by the optimizing natural resources, water, energy and materials use, in addition to minimizing waste production ${ }^{14-16}$. They also consider the reduction or elimination of materials used for building aircrafts or support during the production processes that include intrinsically toxic properties, which are hazardous to the health and safety of people, and to the environment. Sustainable concepts, technologies and materials for aircraft interiors ${ }^{23,24}$ have been developed, although it is still not clear how they are relevant to developing a product with reduced environmental impact and economical benefits due to their compliance with regulatory restrictions.

The interior components such as ceiling, sidewall, furniture, floor and seating are predominantly composite structures. They are composed of a structural material fastened with adhesives and metallic parts, and finished with different materials such as lacquers, paints, wood, synthetic laminates, fabrics and leather.

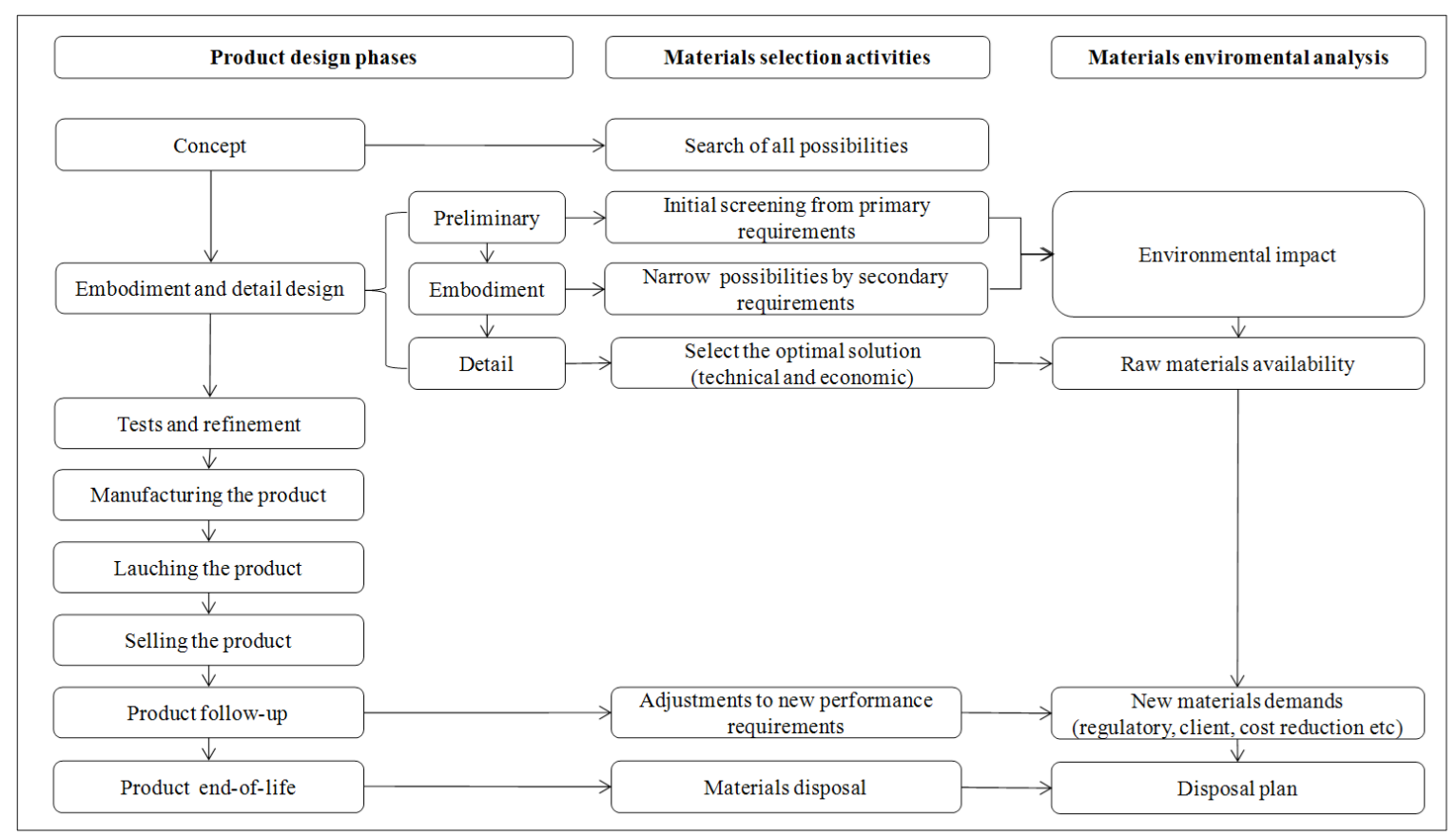

Figure 1: Selection activities and environmental analysis of materials in the product design ${ }^{3,5,6-13}$. 


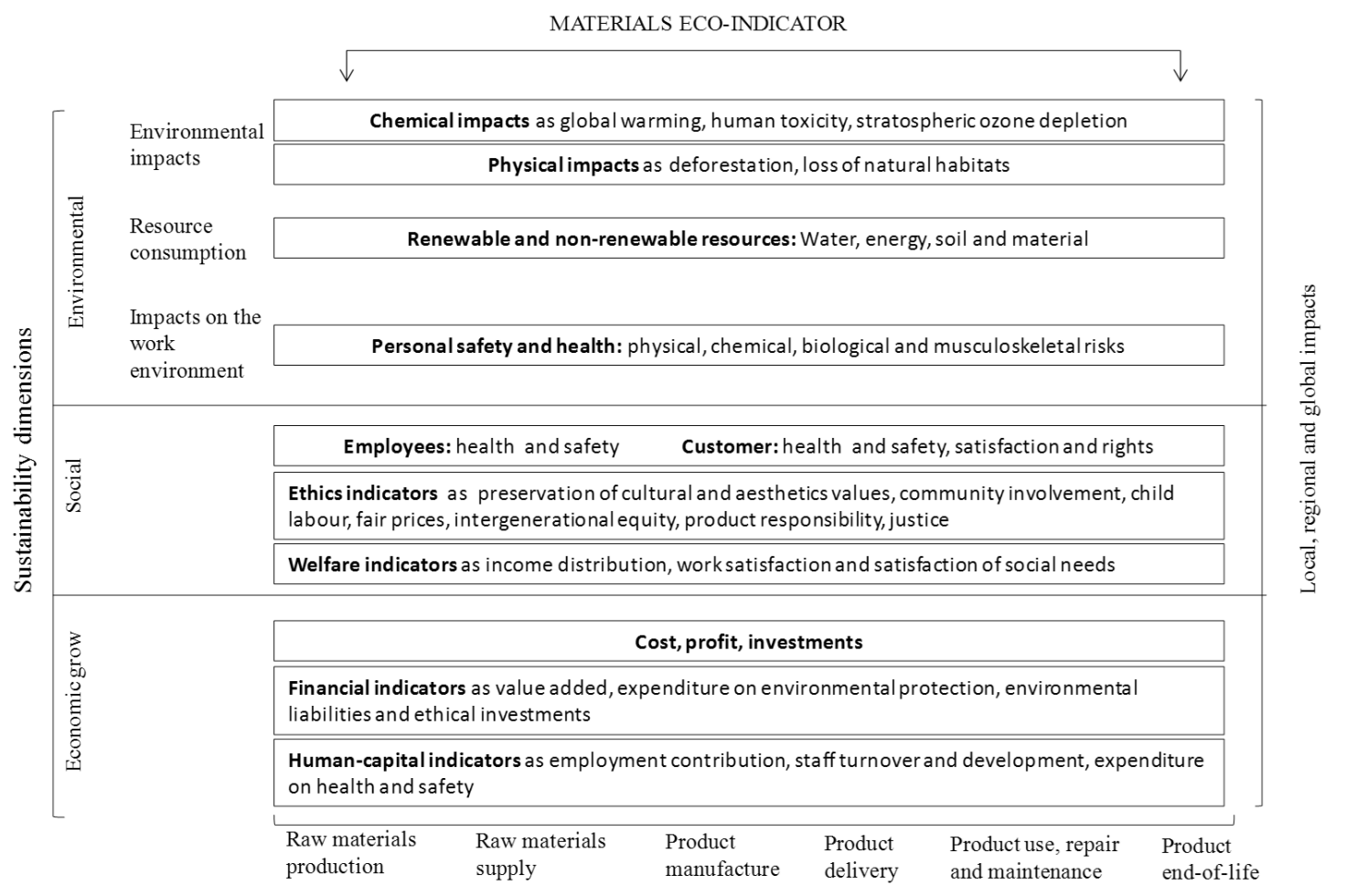

Product life cycle phases

Figure 2: Materials eco-indicator determined by its impact on the product life cycle phases ${ }^{8,12,47,48}$.

The selection of materials is generally restricted to those that have a consolidated use, based on strict technical and aeronautical regulations related to fire and smoke resistance, low density and other specific requirements ${ }^{3,28}$. Table 2 shows the materials currently selected to manufacture interiors of executive aircrafts. Although the importance of eco-friendly design and materials is recognized, there is a lack of systematic studies on the environmental issues regarding these materials, and also methodologies to support the product development of aircrafts.

\section{Materials and methods}

To propose a methodological guide to select materials during the development of components for executive aircrafts, taking into account the environmental issues and the aeronautical and marketing requirements, the following steps were executed:

1- A case study was carried out to fully understand and identify relevant ecodesign strategies, materials requirements and definition of potential eco-indicators for the sustainable design of aircraft interiors;

2- A methodological guide was proposed for the selection of materials, based on materials requirements and indicators for a sustainable design highlighted by the case study, in addition to aeronautical and marketing requirements.
The information was collected from field survey and documentary research. The field survey covered interviews with specialists in the areas of Marketing, Purchasing, Design, Product Design, Materials and Manufacturing Engineering, with experience or relevant knowledge on executive aircraft furniture, in order to identify the factors influencing the decision regarding the materials to be used in the aircraft interior design. The documentary research comprised the relevant technical and scientific publications available in the data bases Web of science, Scopus and Engineering Village, in the bibliographic patent publications data bases Derwent and Espacenet, and the books written by respected authors in the areas of materials selection and product design. It was complemented by available information in the supplier's materials catalogues, web sites of executive jet manufacturers and associations, and also in university thesis and dissertations databases and documents.

The material component selected for the case study was a honeycomb sandwich panel used to produce aircraft interior furniture such as cabinets, doors and dividers. The honeycomb panels represent more than $90 \%$ of the total volume of materials used to build the furniture items, which represent a key differentiation in executive jets compared to other aircraft categories. The configuration of these panels is produced from an aramid honeycomb core facing with phenolic and/or epoxy resins, reinforced by glass fiber ${ }^{29,52}$, as shown in Figure 3. These panels are commonly used by interior aircraft manufacturers. They are also essential to the functional performance of the furniture items. 
Table 1: Product sustainability strategies that affect materials selection in product design.

\section{Design strategies for product sustainability improvement that influence material choices}

Approach

techniques

references

Ecodesign or

Design for

Environment

Design for

Manufacturing

and Assembly

Lean

Manufacturing

- Select materials which low water consumption for primary production

- Reduce energy for transportation and storage of materials

- Optimize logistics by supplier chain engagement with environmental strategy

- Minimize production phases

- Select materials to best suit each processing operation

- Minimize, reuse and recycle production scrap and residues

- Avoid Packing during product production

- Reduce energy for production process and select local energy sources

- Optimize energy use in the production buildings

- Use recycled processing materials

- Reduce use and quantities of processing materials and consumables

- Use processing and consumable materials from renewable sources

- Remove process waste related to:

- Defects: that produces scraps

- Over production: that produces scraps and increase the inventories;

- Inventories: that produces scraps and consumes stock area and energy;

- Over processing: that consumes more materials and energy

- Transport: that consumes more energy

- Waiting: that produces intermediate stocks and use area, energy and may produce scraps

- Remove or minimize processing activities required by the actual technological level but that do not add value from the customer point of view and consumes more materials and energy.

- Reduce energy for product transportation and storage

- Minimize the quantity of material in product packing

- Optimize materials and energy consumption during the product usage and maintenance

Related to reduction of environmental impacts:

- Avoid using toxic materials in all product life phases

- Avoid materials that cause depletion of ozone layer and/or global warming

- Avoid materials with problematic origin (such as deforestation wood)

- Use recycled, renewable and/or bio-compatible materials

- Use raw-materials produced from renewable and environmentally compatible energy resources

- Transport raw-materials to the use point using renewable and bio-compatible energy

- Extend the product lifespan:

- Design to improve the reliability, durability and functionality.

- Use well tried and tested materials for a product with high level of reliability

- Facilitate upgrading, adaptability, maintenance, repair, reuse, remanufacturing

- Extending the lifespan materials:

- Select materials with efficient recycling technologies

- Facilitate material recycling

- Facilitate the product end-of-life collection and transportation

- Minimize different incompatible materials and avoid inseparable composite materials

- If fasteners cannot be eliminated, minimize and standardize them.

- Avoid pigments, additives, materials with unknown composition and substances that interfere with the recycling process

- Avoid processing materials that cause depletion of ozone layer and/or global warming

- Avoid production of hazardous waste in the process stages

- Use renewable and bio-compatible energy to manufacture the product

- Eliminate the source of environmental issues instead of setting up end of pipes treatments in the manufacturing

- Product delivery using renewable and bio-compatible energy

- Avoid toxic materials for use, repair and maintain the product

- Avoid materials that need hazardous waste disposal

- Ensure easy removal of hazardous material for product disposal

- Reuse, re-engineer, recycle rather than landfill or burn for heat recovery 
Table 2: The main materials currently used to produce aircraft interiors.

\begin{tabular}{|c|c|c|}
\hline Material use & Materials for typical interior components & References \\
\hline \multirow{3}{*}{ Interior structures } & $\begin{array}{l}\text { Ceiling and sidewall: } \\
\text { - Phenolic resin panels reinforced with glass or carbon, in solid structures or with honeycomb } \\
\text { aramid fiber paper core }\end{array}$ & 28 \\
\hline & $\begin{array}{l}\text { Furniture (cabinets, doors and dividers) and floor structures: } \\
\text { - Honeycomb sandwich panels: } \\
\text { - Facing materials: aluminum alloy, epoxy or phenolic resin reinforced with glass, carbon or } \\
\text { aramid fibers } \\
\text { - Core materials: aluminum alloy, aramid fiber paper in a honeycomb structure } \\
\text { - Edge filling and reinforcing resins: epoxy based }\end{array}$ & $25,28,29$ \\
\hline & $\begin{array}{l}\text { Seating structures: } \\
\text { - Aluminum alloys } \\
\text { - High temperature thermoplastics as polyethersulfone and polyphenylsulfone, glass or carbon } \\
\text { fiber reinforced }\end{array}$ & 30 \\
\hline Structural jointing & $\begin{array}{l}\text { Union of structural components: } \\
\text { - Epoxy adhesives } \\
\text { - Aluminum and steel alloys (painted, chromed, anodized, gold plated) }\end{array}$ & $31-34$ \\
\hline $\begin{array}{l}\text { Finishing of } \\
\text { structures }\end{array}$ & $\begin{array}{l}\text { Ceiling, sidewall, furniture and seating covers: } \\
\text { - Cotton or wool fabric, natural or synthetic leather } \\
\text { - Decorative thermoplastics such as polyvinyl chloride and polyvinyl fluoride } \\
\text { - Wood veneers and hardwood covered with polyurethane, polyester or acrylic lacquers } \\
\text { - High pressure laminates (decorative paper treated with melanin resin on kraft paper sheets } \\
\text { impregnated with phenolic resin) } \\
\text { - Water or solvent based polyurethane paints } \\
\text { - Polyethylene and polyurethane foams } \\
\text { Flooring covers: } \\
\text { - Nylon and wool carpets, polyvinyl chloride base sheets } \\
\text { - Stone veneers }\end{array}$ & $28,35-44$ \\
\hline Paste the finish & - Epoxy, polyurethane, resorcinol or neoprene adhesive systems, water or solvent based & $25,29,31,45$ \\
\hline
\end{tabular}

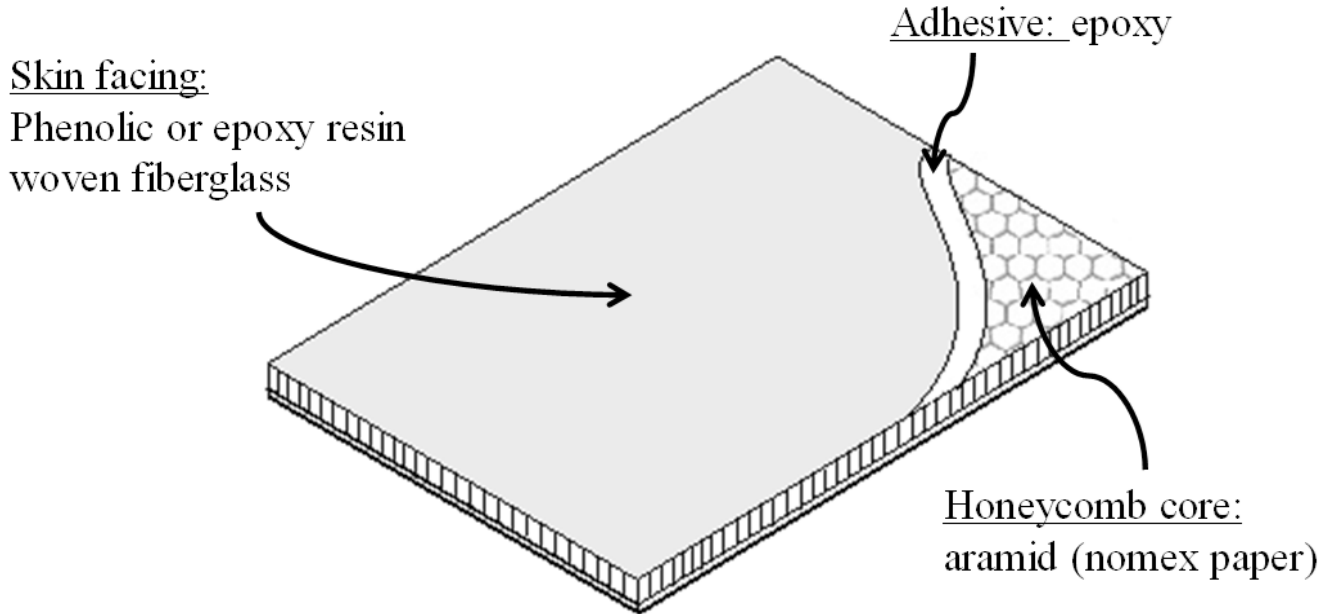

Fire retardant: phosphate based

Figure 3: Honeycomb sandwich panels used in the case study. 
To understand and identify the relevant ecodesign strategies and materials requirements, the case study was based on the mapping of the sandwich panels route through the furniture life cycle and the main concepts reported in the literature about Ecodesign, Design for environment, Design for manufacturing and assembly, and Lean manufacturing.

\section{Results and discussion}

\subsection{The honeycomb sandwich panel life cycle route in executive aircraft interiors}

Figure 4 illustrates the honeycomb sandwich panel route analysis, from the raw materials used to produce the furniture, until their disposal at the end of their life cycle, indicating design strategy opportunities to select more sustainable materials for interior components, as follows:

A) Opportunities related to materials properties:

A1) Reduce or eliminate using materials or substances hazardous to humans and to the environment
A2) Reduce loss of materials and emissions in the manufacturing process

A3) Reduce infrastructure for the material use in manufacturing process

The honeycomb sandwich panels are produced with thermosetting resins that use toxic chemicals and precursors such as phenol, from non-renewable sources. The materials components, although inert in the composite, release hazardous dusts during the furniture manufacturing process in the milling, drilling and sanding activities ${ }^{25}$. These dusts cause skin irritation and respiratory problems if inhaled, and chronic lung disorders with prolonged exposure ${ }^{52}$ Therefore, the use of these materials in the furniture plants, besides requiring the monitoring of human health and use of personal protective equipment, requires special infrastructure in the manufacturing process to collect and dispose of the insalubrious dust. These infrastructures increase energy consumption and $\mathrm{CO}_{2}$ emissions in the cabinet production system not directly associated to the transformation process, affecting the environmental performance of the product.

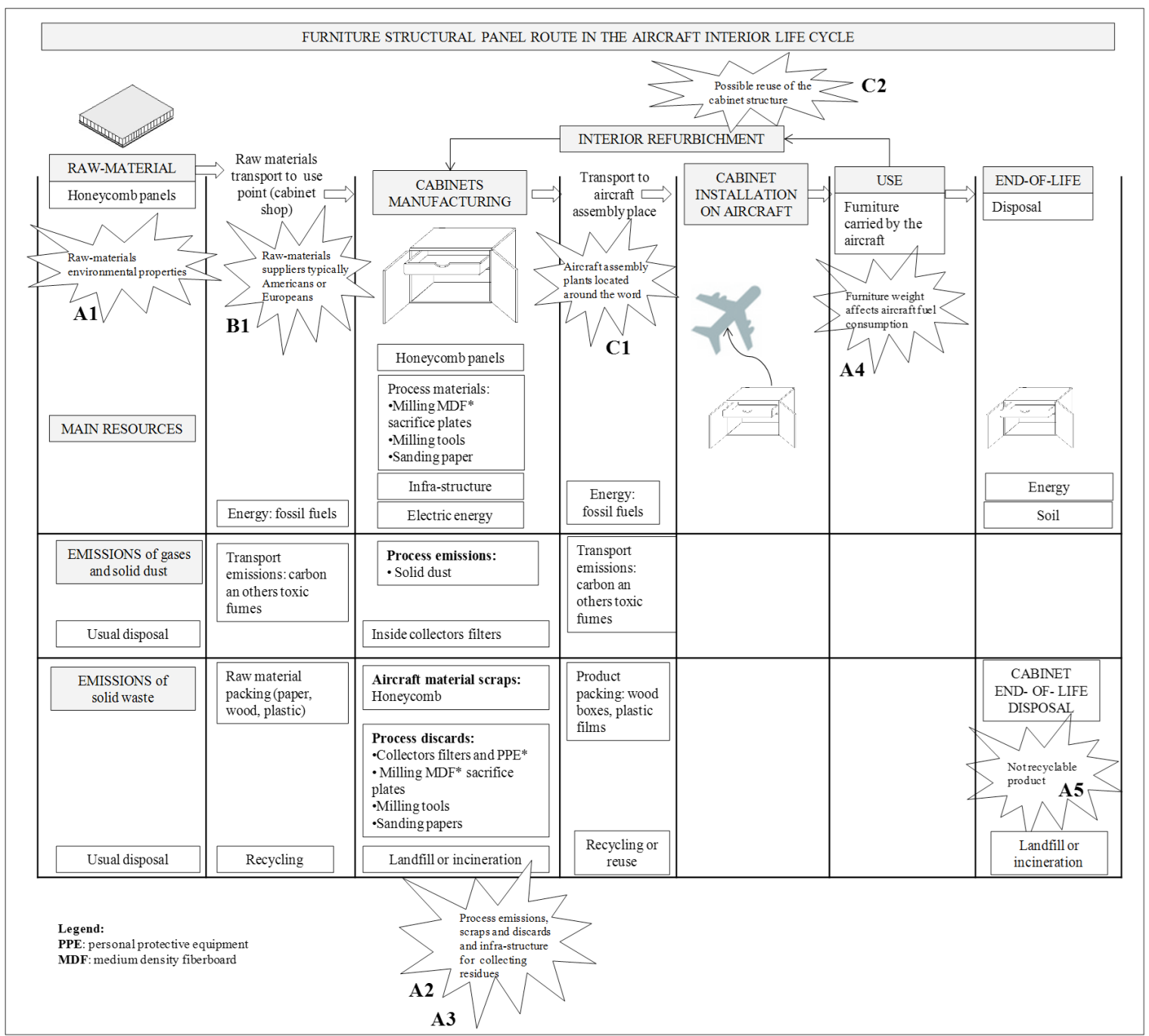

Figure 4: Honeycomb sandwich panel route analysis in the aircraft interior life cycle to produce environmentally friendly furniture. 
A4) Use more lightweight materials to minimize aircraft fuel consumption during the product use phase

Weight is one of the most important properties in aircraft design as it affects fuel consumption when the aircraft is flying, consequently more resources used and more pollution ${ }^{15}$. The aircraft's environmental impact in flight represents about $90 \%$ of total impact considering the other product life cycle phases due to fuel consumption ${ }^{49}$.

\section{A5) Improve end-of-life product disposal}

Regarding the disposal of manufactured sandwich panel scraps, and the end-of-life product, the current practice is landfill or incineration, since it is almost impossible to recycle these materials due to its properties.

Notwithstanding the disposal and recycling difficulties related to the use of this type of sandwich panel, its use in aircraft components have been justified by the long life of the product, produced in relatively small numbers ${ }^{8,50,51}$, and by the panels lightweight properties.

\section{B) Opportunities related do materials provisioning:}

B1) Materials availability and transportation to the plant where they will be used

Regarding the transportation of raw-materials to the use point, most raw-materials manufacturers and suppliers are located in North America or Europe, where the leading aeronautical companies such as Boeing and Airbus are installed. This affects mainly the interior manufacturers not located in North America - Europe axis ${ }^{14}$, whose production will require more energy consumption and will release more carbon dioxide to the atmosphere. In addition, material availability is also impacted by the substantial volumes of materials used by the biggest aeronautical companies, which will affect the offer, demand and cost of materials. Furthermore, local suppliers may be particularly relevant to interior manufacturers located outside North America Europe axis with the possibility to reduce environmental impacts due to the transportation of materials and social benefits by developing local communities.

C) Opportunities related to materials use:

C1) Improve product construction techniques imposed by material properties, which affect the transport of the finished interior to the location where it will be installed in the aircraft in terms of packaging and transported volumes

The most common way to use the sandwich panels to manufacture the aircraft interior cabinets is finalizing the assembly at the plant and transporting big volumes to the location where it will be installed in the aircraft. Since the aircraft production is globalized, big volumes of interior parts are transported across continents. This strategy to produce and transport the cabinets impacts the logistics and energy costs, and also the use of material packaging. Panel joint solutions, strongly related to the composite material properties and structure, could allow using manufacturing and assembly solutions to produce all parts separately and then transport to the client for the on-site assembly, like that used by the residential furniture industry.

\section{C2) Encouraging furniture refurbishing practices}

Interior refurbishing is a common practice for executive aircrafts owing to aesthetical obsolescence and wearing out, which occurs within a twenty year period in the average life cycle. This practice could be made easier if the furniture components use materials and manufacturing techniques that facilitate the removal and replacement of finishing materials, retaining the interior structure, thus extending the interior life-time and minimizing the impacts related to the use of composite materials.

The other materials used to produce aircraft furniture (the jointing and finishing materials), and interior components (as ceilings, sidewalls, floors and seating), shown in table 2, have similar properties to the structural panels in terms of the presence of hazardous substances in the composition, production from non-renewable sources, recycling difficulties and use of manufacturing techniques. These similarities allow expanding the use of identified product design strategies from the case study to the interior components.

These product design strategies translated to materials selection requirements and indicators can be used in the first product development phases to survey and select alternative materials.

Table 3 shows the results of these strategies converted into materials requirements and indicators to explore and select materials in the design of sustainable interiors.

Most of the eco-friendly materials solutions for aircraft interiors found in patent documents seem to be focused on compliance with environmental regulations. For example: a) replacement of blowing foams agents with ozone depletion potential ${ }^{54}$; b) elimination of halogenic compounds in fire-retardants and polymers ${ }^{55}$; c) elimination of hydrogen-chloride group gases during the incineration or disposal of decorative sheets ${ }^{56}$, and; d) elimination of chromates in paints and coatings ${ }^{57}$.

Decorative sheets with reduced emission of volatile organic compounds that improve cabin air quality ${ }^{58}$, and production of synthetic leathers, foams and insulators with less organic solvents ${ }^{59-61}$, also have been patented at the last ten years. In this most recent period, solutions focused on the incorporation of natural fibers to reinforce polymers, and in the application of bio-plastics to produce composite panels also emerged ${ }^{62-66}$. It agrees with the global tendencies to reduce the dependence on non-renewable material sources and worries about materials recycling encouraged by environmental regulations. In the aerospace industry, programs focused in aircraft recycling are conducted since 2006-2007 $7^{18-19}$.

Specifically for the current panel skins of phenolic and/or epoxy resins, glass fiber reinforced, there are, for example, the following patented solutions: a) substitution of glass fibers to natural fibers, as coir fiber ${ }^{63}$; b) phenolic resins with low free formaldehyde and phenol ${ }^{64}$, and; c) polyamide base bio-plastic reinforced with castor plant fibers ${ }^{67}$. 
Table 3: Exploring materials requirements and indicators to design sustainable aircraft interiors, from mapping strategies.

\begin{tabular}{|c|c|c|}
\hline Design strategy & Materials requirements & Possible materials indicators \\
\hline A1 & $\begin{array}{l}\text { Non hazardous } \\
\text { (Supported by laws and regulations) }\end{array}$ & Toxicity \\
\hline \multirow[b]{2}{*}{$\mathrm{A} 2$} & $\begin{array}{l}\text { Raw-material shape near to the final shape } \\
\text { of the product }\end{array}$ & $\begin{array}{l}\text { Efficiency of materials used: } \\
\text { - } \% \text { of raw materials converted to product }\end{array}$ \\
\hline & $\begin{array}{l}\text { Reduced emission of dust during mechanical } \\
\text { working }\end{array}$ & $\begin{array}{l}\text { Materials energy requirements: } \\
\text { - Energy consumed for direct processing of raw-materials x } \\
\text { energy consumed for containing and disposing residues } \\
\text { - \% of energy used from renewable sources }\end{array}$ \\
\hline A3 & $\begin{array}{l}\text { Non specific infrastructure demands for raw } \\
\text { material processing }\end{array}$ & Materials infrastructure costs needed for manufacturing \\
\hline A4 & Low weight & Density \\
\hline A5 & $\begin{array}{l}\text { Materials recyclability potential for the } \\
\text { product }\end{array}$ & Amount of materials waste recycled \\
\hline $\mathrm{B} 1$ & Use of local materials & $\begin{array}{l}\text { Materials energy requirements: } \\
\text { - Energy consumed to transport materials to the use point } \\
\text { - } \% \text { of energy used from renewable sources }\end{array}$ \\
\hline $\mathrm{C} 1$ & $\begin{array}{l}\text { Materials joining techniques that allow to } \\
\text { assemble the interior components at the } \\
\text { location where it will be installed in the } \\
\text { aircraft }\end{array}$ & $\begin{array}{l}\text { Materials energy requirements: } \\
\text { - Energy consumed to transport product to the use point } \\
\text { - \% of energy used from renewable sources } \\
\text { Materials packaging requirements: } \\
\text { - Volume and type of packaging materials used }\end{array}$ \\
\hline $\mathrm{C} 2$ & Materials reuse potential for the same use & Amount of reused materials \\
\hline
\end{tabular}

The two first solutions keep the current materials concept and improve the sustainability by adding a natural material, or reducing the toxicity of the synthetic material. However, they do not solve the issues regarding the material recyclability and end-of life disposal. The third patented solution is more promising in all environmental aspects, since it proposes to reduce the dependence of non-renewable material sources, and to be biodegradable and no-toxic. And it can be combined with solutions for sustainable honeycomb cores as cellulose paper honeycomb ${ }^{68}$, as alternative to the current aramid honeycomb cores.

However, the panel solutions should be validated with the aircraft interior project requirements. The main ones are flammability, strength and stiffness, low weight, and resistance to the aircraft environmental operations conditions along the product life cycle (temperature, humidity and pressure). The panel is also required to be physically and chemically compatible with finishing materials, and with joining materials and techniques.

Another important concern involving the use of the natural materials is their tendency to absorb water, mainly the ones containing cellulose in the composition. Make these materials more resistant to water is important do reduce infrastructure energy costs to keep them stable during the manufacturing process. This is also important to avoid product defects as warping, cracks and detachments of finishing materials ${ }^{69}$.

The use of natural materials for the aircraft interior application should also consider how to stabilize chemical composition variations, since they can affect the reproducibility of flame retardant properties.

Other promising environmental solutions covering the panel skin and cores, but that also require validation, are the sandwich honeycomb panels produced from polylactide or polylactic acid or corn $\operatorname{starch}^{65}$, and a balsa wood plateshaped element with fiber composite reinforced faces ${ }^{70}$ There are also the composite solid panels with core and faces of biopolymeric resin containing fibers ${ }^{66}$.

Although there are probably material weight concerns of using solid panels, they have the advantage of reducing or eliminating the use of the epoxy resins to reinforce honeycomb panels areas to attach metallic joining elements as inserts, hinges and latches. There is also the advantage of reducing or eliminating the resins use to fill the exposed honeycomb cores on the edge of the aircraft parts.

The resin parts edge filling is a process step required to apply finishing materials as paints and laminates. It can be bypassed through the insertion and gluing of plastic or wood edge close-out elements ${ }^{25,71}$. However, the available materials for edge close-out are not always adequate to project aesthetic requirements.

\subsection{Proposal of a product development guide to select materials for sustainable aircraft interiors}

The materials selection process to design an environmentally friendly product requires specific analysis in almost all product development phases, as shown in Figure 5.

In the Concept phase of product design, an environmental mapping is suggested to the materials survey, and also to verify environmental regulations and restrictions for the use of materials in countries where the aircraft will potentially be sold and used. Applying a mapping strategy, which can be performed along the lines of that applied in the case study, is the basis for identifying product design strategies to be extended in materials requirements and indicators for the following product design stages. Besides the environmental analysis, the materials survey must also be performed considering a customer analysis. The executive aircraft client analysis should focus on aspects related to the 


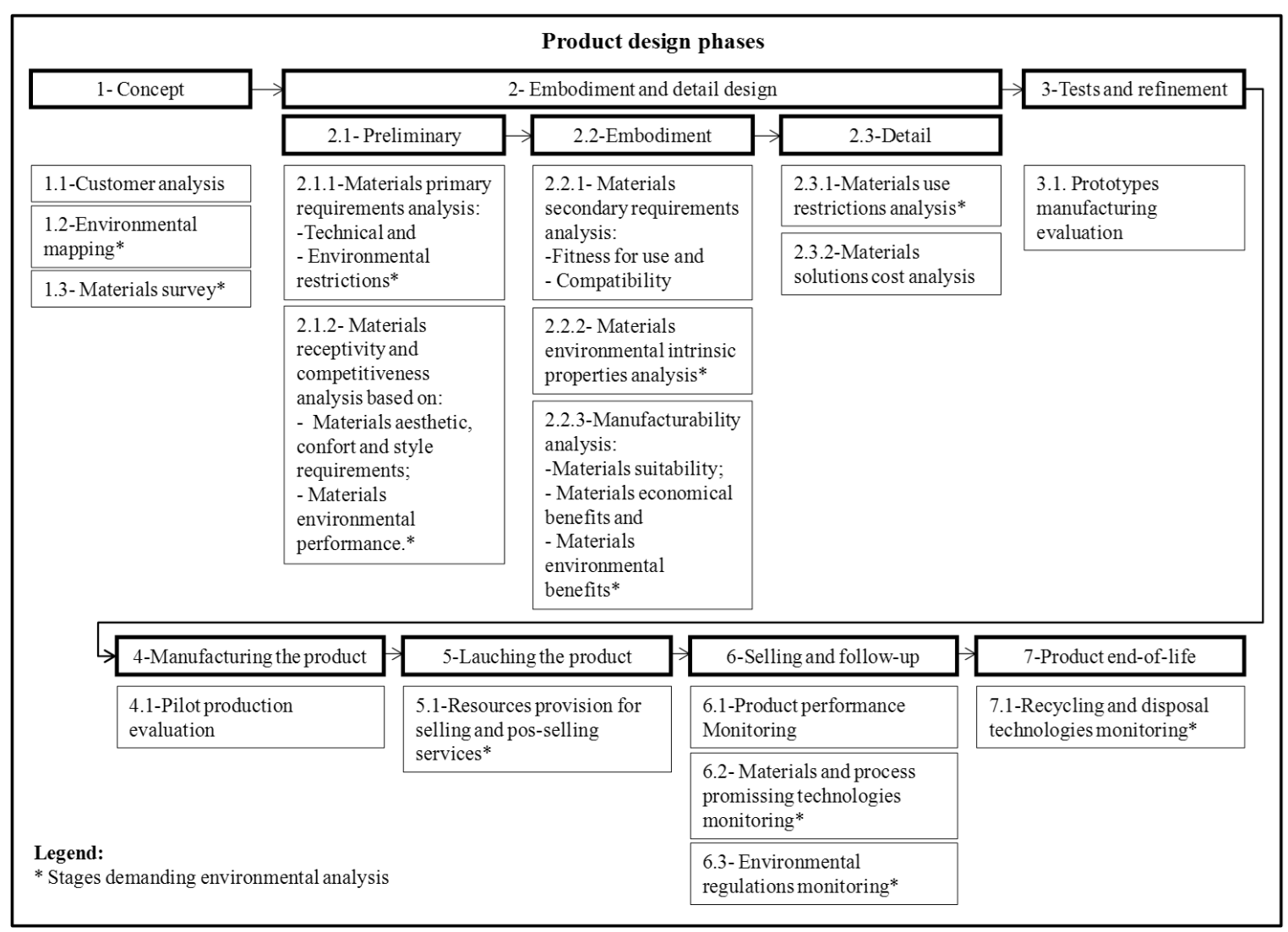

Figure 5: Roadmap of materials selection needed in product development for environmentally friendly design.

aircraft size and use, cultural and regional aspects and the tendencies of products and settings used by the clients. These aspects will be used to determine the relevance of materials requirements such as robustness, durability, functionality, aesthetics, personalization, comfort, and environmental concerns. The Concept activities can be implemented, as shown in Appendix A, to identify materials requirements and to survey materials possibilities.

In the Embodiment and Detail design of product development, the analysis of materials primary requirements is proposed at the Preliminary stage, including environmental regulations and aeronautical design such as aircraft flammability and structural certification, as shown in Appendix B. Then, from the materials selected, the next choices should evaluate materials receptivity and possible competitive differentiation considering environmental benefits required by regulations, in addition to aesthetics, comfort and style issues.

In the second Embodiment stage shown in Appendix B, the materials selection activities should consider the analysis of aeronautical secondary design requirements (for example, substrate-adhesive physical-chemical compatibility) followed by environmental issues. The environmental analysis in this phase should comprise materials requirements such as those for the honeycomb case study shown in Table 3, including non-hazardous, low weight and recyclability/reuse potential, besides environmental improvements during manufacturing. The manufacturing can be improved by reducing the materials used (aircraft and consumables), reducing the use of energy and water, reducing costs and investments in infrastructure, reducing costs to monitor and conserve worker's health, as well as reducing the need of process scraps and residues disposal.

In the Detail stage of the Embodiment and Detail design step shown in Appendix B, the environmental analyses are related to the company's external and internal setting. The evaluation of the external setting should comprise the use of restricted materials related to world market, materials availability and supply conditions in terms of distances (affects energy consumption and carbon emissions) and development possibilities of local suppliers (that affects the social dimension of sustainability). The internal setting should evaluate the experience of the materials used to avoid losses due to low reliability of the manufacturing process and of the product.

Considering the materials foreseen in the product Concept phase, it is believed that most of them will not meet all the main project requirements of the aircraft interior. Then, an environmentally friendly product design should consider investments in materials development. Other investments should be in collecting and organizing non-existing or available information about the environmental performance of these new materials formulated for the aeronautical area, and for those currently used, to compare alternative solutions.

Adapting technologies and materials to the aeronautical context should include identifying organizations and suppliers that have the knowledge and background regarding eco-efficient 
product development. Thus, considering the complexity of the subject matter and the level of product globalization, the structuring of consortiums among manufacturers and suppliers is seen as achievable to develop and make available sustainable technologies and materials for aircraft interiors ${ }^{23,24}$, such as the earlier studies regarding alternative solutions to recycle aircrafts at the end-of-life, PAMELA ${ }^{18}$ and AFRA ${ }^{19}$.

Notwithstanding the initiatives to build sustainable aircraft interiors with positive impact in terms of competitiveness and attractiveness, and the technologies developed to reduce aircraft fuel consumption, the executive aircraft will continue to be a product of high fuel consumption per capita during the use phase. And minimizing the impacts in this area should occur through emission compensation actions financed by the aircraft owners ${ }^{53}$.

The next product design phase for environmental issues regarding materials selection should be the Launch of Product, after the Tests and Refinement, and Product Manufacturing, as shown in Appendix C. The launched product should have environmental appeal and be easily to refurbish. The maintenance and repair of interior parts should be simple to perform, consume few resources and use environmentally friendly materials and procedures. If strategies such as carbon emission compensation during product use are offered to the clients ${ }^{53}$, it should have a structured program.

In the Product Selling phase shown in Appendix $\mathrm{C}$, materials use should be monitored to anticipate any adjustments required by environmental regulations. In this product design phase, and in the next Product end-of-life, materials and process technologies that were disregarded during the materials selection process, because they are not sufficiently mature or not applicable for aeronautical use, may be evaluated for possible implementation during the serial production phase. These improvements could be performed to increase environment performance, differentiation or profits.

\section{References}

1. General Aviation Manufactures Association. General Aviation Statistical Databook \& 2014 Industry Outlook [Internet]. Washington, (DC): GAMA; 2014. [cited 2014 Jul 6]. Available from: http://www.gama.aero/files/GAMA \%202013\%20 Databook-Updated-LowRes.pdf

2. Bédier C, Vancauwenberghe M, Van Sintern W. The growing role of emerging markets in aerospace. Insights \& Publications [Internet]. april 2008 [cited 2011 Nov 14]. Available from: http://www.mckinsey.com/insights/travel_transportation/ the_growing_role_of_emerging_markets_in_aerospace

3. Costa FR. Situação atual e perspectivas de utilização de materiais no interior de aeronaves executivas [Dissertaçao]. São Carlos: Universidade Federal de São Carlos; 2009.

4. Aerospace Technology Steering Group. UK Aerospace Technology - An Evolution [Internet] United Kingdom: National Aerospace Technology Strategy; 2011. [cited 2011 Nov 14]. Available from: https://connect.innovateuk.org/documents/2967241/3676688/ $\mathrm{UK}+$ Aerospace+Technology+-+An+Evolution.pdf/e75e3f3b6c0b-4283-a0bd-c4b4af529ff2
Additionally, the Product end-of-life phase will require an organized network of receivers of discarded products, as well as interior disposal procedures.

\section{Conclusion}

This study proposes a methodological guide to explore and select materials for executive aircraft interiors, and strategies, materials requirements and possible indicators for the design of a more sustainable product. Some of the development strategies regard solutions based on light, non hazardous materials, that use a percentage of recycled raw-materials, compatible with the environment, from renewable sources, produced by local suppliers and that result in simple refurbishing practices. Other strategies include manufacturing technological solutions that produce low quantities of scraps and residues, and others which will enable improving the transport of the aircraft interior to the place where it will be installed in the aircraft. Materials toxicity, density, recyclability and reuse potential, energy use efficiency and resource requirements for supply and processing, seem to be the most relevant indicators to be considered during the design of interior components.

Promising materials solutions covering the sustainable indicators for the current honeycomb panels seem to be the bio-polymers composites reinforced with natural fibers, and with solid cores. However, these solutions need validation on the aircraft interior project mainly concerning the materials properties related to flammability, strength and stiffness, low weight, moisture resistance, durability in the aircraft operation conditions, and compatibility with de adjacent materials.

\section{Acknowledgements}

The authors are grateful to the Programa de Pós-graduação em Ciência e Engenharia de Materiais da Universidade Federal de São Carlos, and to the Núcleo de Informação Tecnológica em Materiais, for supporting this work.

5. Farag M. Materials and process selection for engineering design. 2. New York: CRC Press; 2007.

6. Ashby MF. Material Selection in Mechanical Design. United Kingdom: Elsevier; 1999.

7. Rozenfeld H, Forcellini FA, Amaral DC, Toledo JC, Silva SL, Alliprandini DH, et al. Gestão de Desenvolvimento de Produtos - Uma referência para a melhoria do processo. São Paulo: Saraiva; 2006.

8. Ashby MF. Materials and the Environment - Eco-Informed Material Choice. United Kingdom: Elsevier; 2009.

9. Giudice F, La Rosa G, Risitano A. Materials selection in the life-cycle design process: a method to integrate mechanical and environmental performances in optimal choice. Materials and Design. 2005;26(1):9-20. doi:10.1016/j.matdes.2004.04.006

10. Kampe SL. Incorporating Green Engineering in Materials Selection and Design. In: 2001 Green Engineering Conference: Sustainable and Environmentally-Conscious Engineering; 2001. Proceedings. Roanoke, Virginia: Virginia Tech's College of Engineering and the U.S. Environmental Protection Agency; 2001. 
11. Ibeh CC, Bhattarai D. AIMSeT: Advanced Innovative Materials Selection Techniques [abstract]. In: Annual Conference 2003. American Society for Engineering Education. Proceedings. Nashville, Tennessee; American Society for Engineering Education; 2003. https://peer.asee.org/aimset-advancedinnovative-materials-selection-techniques

12. Wenzel H, Hauschilld MZ, Alting A. Environmental assessment of products: methodology, tools and case studies in product development. Dordrecht: Kluwer Academic; 1997.

13. Pigosso DC. Ecodesign maturity model: a framework to support companies in the selection and implementation of ecodesign practices. [Thesis]. São Carlos: Universidade de São Paulo; 2012. http://tese_DanielaPigosso_final.pdf

14. Embraer. Sustainability at Embraer [Internet]. São José dos Campos: EMBRAER [cited 2014 Feb 19]. Available from: http://www.embraer.com.br/Documents/sustentabilidade-eng. pdf

15. Airbus Group. Design for Environment-Eco efficiency and sustainability - G6 - Issue 1 [Internet]. Available from: [cited 2014 Feb 18]. http://www.airbus.com/company/environment/ documentation/

16. The Boeing Company. 2013 Environment Report - Building a Better Planet [Internet]. [cited 2014 Dec 14]. Available from: http://www.boeing.com/aboutus/environment/environment_ report_13/2013_environment_report.pdf

17. European Commission. REACH - Registration, Evaluation, Authorization and Restriction of Chemicals [Internet]. Last updated 11/11/2015. [cited 2011 Dec 17]. Available from: $\mathrm{http} / / /$ ec.europa.eu/environment/chemicals/reach/reach_en.htm

18. Airbus Group. Eco-Efficiency. Process for advanced management of end of life aircraft-PAMELA [Internet]. [cited 2014 Nov 18]. Available from: http://www.airbus.com/innovation/ecoefficiency

19. Aircraft fleet recycling association - AFRA [Internet] . Washington, DC: Aircraft Fleet Recycling Association. [cited 2014 Nov 18]. Available from: http://www.afraassociation.org

20. European Commision. Council of the European Union. Directive 2000/53/EC on end-of life vehicles: guidance document [Internet]. Version 1- January 2004. [cited 2014 Dec 14]. Available from: $\mathrm{http}: / /$ cc.europa.eu/environment/waste/pdf/guidance_doc.pdf

21. Bralla JG. Design for excellence. New York: McGraw-Hill; 1996.

22. Womack JP, Jones DT. Lean Thinking: Banish Waste and Create Wealth in Your Corporation. New York: Free Press, Simon \& Schuster; 1996.

23. Cayley Consortium. Layman's Report. Industrial implementation for new flat panels from renewable polymers and natural fibre reinforcements for the aeronautical industry [Internet]. Braunschweig, Germany; 2013 [cited 2014 Dec 26]. Available from: <http://www.cayley.eu/fileadmin/cayley/media/docs/s_ Report.pdf

24. Consortium AMORIN/COURO AZUL/INEGI/SET. Life Ligther, Integrated, Friendly, Eco-Efficient Aircraft Cabin. [Internet] Special Edition June 2011. [cited 2011 Feb 18]. Available from: http://life.inegi.up.pt/Project-Life_2011.pdf

25. Hexcel. Sandwich panel fabrication technology [Internet]. Duxford; 2001. [cited 2012 Dec 16]. Available from: http:// www.hexcel.com/Resources/DataSheets/Brochure-Data-Sheets/ Sandwich_Panel_Fabrication_Technology.pdf

26. Tseng ML. Modeling sustainable production indicators with linguistic preferences. Journal of Cleaner Production. 2013;40:46-56. doi:10.1016/j.jclepro.2010.11.019
27. Yuan C, Zhai Q, Dornfeld D. A three dimensional system approach for environmentally sustainable manufacturing. CIRP Annals-Manufacturing Technology. 2012;61(1):39-42. doi:10.1016/j.cirp.2012.03.105

28. Committee of Fire and Smoke Resistant Materials for Commercial Aircraft Interiors. Fire and Smoke Resistant Interior Materials for Commercial Transport Aircraft. Washington D.C.: National Academies Press; 1995.

29. Hexcel. Honeycomb Sandwich Design Technology [Internet]. Dusford; 2000. [cited 2012 Dec 16]. Available from: http:// www. hexcel.com/Resources/DataSheets/Brochure-DataSheets/ Honeycomb_Sandwich_Design_Technology.pdf

30. BASF Aerospace. Aerospace Materials for Seating Components [Internet].Wyandotte, MI [cited 2014 Dec 12]. Available from: http://aerospace.basf.com/seating-components/

31. 3M Industrial Adhesives \& Tapes. $3 M^{\mathrm{TM}}$ Scotch-Weld ${ }^{\mathrm{TM}}$ Epoxy Adhesive DP460 Off-White [Internet]. [cited 2014 Aug 28]. Available from: http://solutions.3m.com/wps/portal/3M/en_US/Adhesives/ Tapes/Products/ /3M-Scotch-Weld-Epoxy-Adhesive-DP460-OffWhite-400-mL-6-per-case? $\mathrm{N}=6081606+4294871468 \& \mathrm{rt}=\mathrm{rud}$

32. Henkel Corporation Loctite. The adhesive sourcebook [Internet]. Vol 5. [cited 2014 Dec 27]. Available from: http://www.gbs.ca/ cat/Loctite_LT3355v5_FullCatalog.pdf

33. Huntsman Enriching lives through innovation. Advanced Materials - Aerospace Materials for Production and Assembly - Selector Guide [Internet]. 2013. [cited 2014 Jun 23]. Available from: http:// www.huntsman.com/advanced_materials/Media\%20Library/a MCED5570E284BD76EE040EBCD2B6B7A1B/Industries MCEFD19E1A181BDB8E040EBCD2B6B77C9/Aerospace\%20 $\% 20 \% 20$ Defense_MD0A897C864EA124EE040EBCD2B6B72D4/ files/US\%20Aerospace\%20Selector\%20Guide\%202013.pdf

34. ETA Global Inc. Aircraft Inserts and Studs [Internet]. Palestine, Texas. [cited 2012 Jan 22] Available from:http:// aircrafthardwarefasteners.etaglobal.com/item/aircraft-threadedfasteners/aircraft-inserts-and-studs-2/item-1017?

35. Spectra. Interior Products [homepage on the Internet]. WinstonSalem, North Carolina [cited 2014 Aug 28]. Available from: http://www.spectra-ip.com/

36. Kydex Thermoplastic sheets. For production high-performance aircraft interior components [Internet]. Bloomsbrug, PA. [cited 2014 Dec 14]. Available from: http://www.professionalplastics. com/professionalplastics/KYDEX-Aircraft_Interiors.pdf

37. Dupont. Tedlar polyvinyl fluoride (PVF) films - general properties. [Internet]. [cited 2014 Dec 14]. Available from: http:// www.dupont.com/content/dam/assets/products-and-services/ membranes-films/assets/DEC_Tedlar_GeneralProperties.pdf

38. Decrane Aerospace. Carl F Booth veneer. [Internet]. [cited 2011 Nov 20]. Available from: http://decraneaerospace.com/ index.php?option $=$ com content $\&$ view $=$ article $\& i d=75 \&$ Item id $=126$

39. Nascimento GC. Avaliação da influência de intempéries na qualidade superficial de sistemas poliméricos utilizados em acabamento de mobiliário aeronáutico. [Thesis]. São José dos Campos: Instituto Tecnológico de Aeronáutica; 2013.

40. Wilsonart. Wilsonart fire-rated laminates. [Internet]. [cited 2011 Dec 17]. Available from: http://www.wilsonartcontract. com/productlib/ techdata/laminate/FireRated.pdf

41. PPG Aerospace. Commercial/civil aviation - interior cabin coatings: desothane ${ }^{\circledR}$ hs cabin interior topcoats / ca 8400 series. [Internet]. [cited 2016 Aug 26]. Available from: http:// www.ppg.com/coatings/aerospace/coatings/coatingsproducts/ Documents/CA8400_Desothane_HS_Interior_Cabin_Coating. pdf 
42. Aerofoam Industries. Cushion materials. [Internet]. [cited 2014 Dec 14]. Available from: http://www.aerofoams.com/ Aircraft-Seating/Cushion-Materials.

43. Aerofloor. Aerofloor products. [Internet]. [cited 214 Dec 14]. Available from: http://www.aerofloor.com/products

44. List. Stone flooring. [Internet]. [cited 2014 Dec 14]. Available from: http://www.list.at/eng/Air/Innovations/Stone-Flooring

45. $3 \mathrm{M} .3 M^{\mathrm{TM}}$ scotch-weld ${ }^{\mathrm{TM}}$ neoprene high performance contact adhesive EC-1357. [Internet]. [cited 2014 Aug 28]. Available from: http://solutions.3m.com/wps/portal/3M/ en US/GovernmentSolutions/Home/ProductInformation/ ProductCatalog/ /3M-Scotch-Weld-Neoprene-High-PerformanceContact-Adhesive-EC-1357-Pint-12-per-case?N=7577534+59 $28575+3294569346 \& \mathrm{rt}=\mathrm{d}$

46. Edwards K. Towards more strategic product design for manufacture and assembly: priorities for concurrent engineering. Materials and Design. 2002; 23(7): 651-656.

47. Joung CB, Carrell J, Sarkar P. Categorization of indicators for sustainable manufacturing. Ecological Indicators. 2013; 24:148-157. DOI: 10.1016/j.ecolind.2012.05.030

48. Azapagic A, Perdan S. Indicators of sustainable development for industry: a general framework. Process Safety and Environmental Protection. 2000; 78(4): 243-261.

49. Howe S, Kolios AJ and Brennan FP. Environmental life cycle assessment of commercial passenger jet airliners. Transportation Research Part D: Transport and Environment. 2013; 19:34-41.

50. Scelsi L, Bonner M, Hodzic A, Soutis C, Wilson C, Scaife R and Ridgway K. Potential emissions savings of lightweight composite aircraft components evaluated through life cycle assessment. Express Polymer Letters. 2001; 5(3): 209-217.

51. Duflou JR, De Moor J, Verpoest I and Dewulf W. Environmental impact analysis of composite use in car manufacturing. CIRP Annals-Manufacturing Technology. 2009; 58(1):9-12.

52. MC Gill Corporation. Material safety data sheet - GILLFAB 5071/5075 - sandwich panels composed of fiberglass fabricreinforced phenolic facing skins bonded to a nomex aramid honeycomb core. [Internet] [cited 2014 Jun 23].Available from: http://www.mcgillcorp.com/public/msds/MSDS_115.pdf

53. Aviation Today. Embraer launches execucare environmental program. [Internet] Monday, june 2, 2008. [cited 2014 Dec 24]. Available from http://www.aviationtoday.com/regions/usa/ Embraer-Launches-ExecuCare-Environmental-Program_22348. html\#.VF7URfnF_Xo

54. 3M Innovative Properties CO. Dams RJ, Dams J. Process for preparation of polymeric foam using fluorinated ketones as blowing agents. WO0024814 A1. 1999.

55. Huizhou Changyi New Materials CO Ltd. Du C, Lin H, inventors. Halogen-free flame retardant for PA66 and environment-friendly flame-retardant PA66 material prepared thereby. Chinese patent CN104119676 A. 2014.

56. Toyobo CO. Abe K, Fujino H, Atsuji T, Endo S, Hara A, Tsujii S and Eto Y, inventors. Decorative sheet for ornamentation. Japan patent JP2004106411 A. 2002.

57. Jung C, Shimakura T, Maurus N, Domes H, Schinzel M, Bittner $\mathrm{K}$, Kolberg T, Wietzoreck H, inventors. Method for pretreating and subsequently coating metallic surfaces with a paint-type coating prior to forming and use of substrates coated in this way. EP1330499 (A2); 2001.

58. Dainippon Printing. Mitsubishi C, Showa I, Kogyosho KK, Soejima Y, Narita T, Tanaka M, Nishikawa H, Kano N, inventors. Decorative sheet, water base resin for coloring decorative sheet, and water base coating liquid for coloring decorative sheet. Japan patent 2008023752; 2006.

59. Int Park Creativity. Cuero RR, Melo RG, inventors. Polyurethane biofoams derived from natural products and methods of making and using thereof. World Patent WO 2015017847 A1. Bogotá, 2014. Available from: https://patentscope.wipo.int/search/en/ detail.jsf?docId=WO2015017847

60. Toray Ind Inc. Mitsuishi T, Koide A, Matsuzaki Y, inventors. Leather-like sheet-shaped material and method for producing the same. Japan patent JP2012136800. 2010.

61. Korwin-Edson ML, O' Leary RJ, Quinn RE, Olang F, inventors. Room temperature crosslinked foam. United States patent US2008161432 A1. 2007.

62. Hanil e Hwa CO Ltd. Kim K, Ji S. Natural fiber polymer composite and eco-friendly lightweight base material for automotive interior. United States patent EP2881249 A1. 2014.

63. Acetylated Fibres Ltd. Chandler B, Oliver PC, Dowdall C, inventors. Hydrophobised fibres and their uses. WO2010112896-A1. 2010.

64. Boettcher A, Pilato L. The value of phenolic resins for advanced fiber reinforced systems: a short review. Sampe Journal. 2015;51(2):38-40.

65. Bremer C, inventor. Sandwich structure for use in booth and store constructions, has core layer arranged between two surface layers, where one of core and surface layers is formed from material, which consists of polylactide or polylactic acid or corn starch. German patent DE102008058534 A1. 2008.

66. Boeing Company. Gonzalez-Garcia A, Martin PP, Lapena N, Wonneberger M, inventors. Fire resistant sustainable aircraft interior panels. United States patent US2015190987 A1. 2014.

67. Airbus Operations Ltd. Heitzmann M, Lindenberger B, $\mathrm{Ng} \mathrm{C}$, inventors. Composite material. United States patent WO2010142774 A1. 2010.

68. Hexcel Corp. Hookham N, Lee A, inventors. Forming process for cellulose paper based honeycomb structures. United States patent EP1195241 A2. 2003 Jul 22.

69. Edwards K, Deng YM. Supporting design decision-making when applying materials in combination. Materials and Design. 2007;28:1288-1297.

70. Yokohama Rubber CO Ltd. Taguchi Y, Kobayashi T, Hirose A, inventors. Aircraft interior panel material and manufacturing method therefor. Japan patent WO2015050239 A1. 2014.

71. Hexcel Corp. Heitkamp RR, Iler TH, Danver D, Cao L, Boyer $\mathrm{R}$, inventors. Environmentally safer process of manufacturing honeycomb products for use in composite materials using a water-based phenolic thermosetting resin and the products made thereby. United States patent US5711992 A. 1995. 
Appendix A: Activities in the Concept phase of the product development guide to select materials for sustainable aircraft interiors.

\section{Activities in the Concept phase}

\section{Customer analysis}

A1) Determine the purpose of aircraft use.

A2) Determine aircraft operators.

A3) Determine aircraft category based on its weight, size or range, and average flight duration.

A4) Determine aircraft world region use and cultural aspects of potential clients, to whom the materials should reflect values, perceptions, and quality concepts.

A5) Verify material tendencies in residences, work places, leisure and transport used by the potential clients.

A6) Verify material settings used in competing aircrafts of the same category, to identify competitive differentiation opportunities.

Environmental analysis

A7) Verify environmental regulations and restrictions for materials use in countries where the aircraft will potentially be sold and used.

A8) Map current product systems for aircraft interior to analyze all life cycle phases, comprising economical and environmental issues.

A9) Define targets and strategies for the product from identified restrictions (A8), and other benefits associated to economical and social issues. Define materials requirements and indicators.

Materials survey based on customer and environmental targets

A10) Materials forecasting based on customer definition, identified tendencies, and environmental targets.

Appendix B: Product development guide to select materials for sustainable aircraft interiors in the Embodiment and detail design phase.

\begin{tabular}{|c|c|c|c|}
\hline \multicolumn{2}{|r|}{ Embodiment and detail design phase } & \multicolumn{2}{|c|}{ Materials requirements } \\
\hline Phase & Activities & $\begin{array}{l}\text { From aeronautical project } \\
\text { and clients }\end{array}$ & For sustainable design \\
\hline \multirow{2}{*}{ 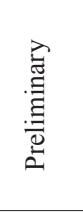 } & $\begin{array}{l}\text { A11) 1st Filter: primary technical } \\
\text { requirements and environmental } \\
\text { regulations }\end{array}$ & $\begin{array}{l}\text { - Flammability. } \\
\text { - Structural certification }\end{array}$ & $\begin{array}{l}\text { - Meet environmental regulations in } \\
\text { the countries where the product will } \\
\text { be manufactured and sold }\end{array}$ \\
\hline & $\begin{array}{l}\text { - A12) 2nd Filter: materials receptivity } \\
\text { and product competitive differentiation; } \\
\text { including environmental issues }\end{array}$ & - Aesthetics, comfort and style & $\begin{array}{l}\text { - Environmental appeal for } \\
\text { competitiveness and client } \\
\text { receptivity }\end{array}$ \\
\hline \multirow{3}{*}{ 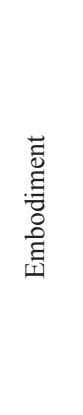 } & $\begin{array}{l}\text { - A13) 3rd Filter: secondary requirements } \\
\text { of aeronautical design, specifically for } \\
\text { materials use, and materials compatibility }\end{array}$ & $\begin{array}{l}\text { - Resistance to: cleaning products } \\
\text { and foods, abrasion, U.V. radiation, } \\
\text { wear, humidity and temperature } \\
\text { variations during aircraft operation }\end{array}$ & - \\
\hline & $\begin{array}{l}\text { A14) 4th Filter: environmental properties } \\
\text { of materials and effect of the materials on } \\
\text { the weight of parts }\end{array}$ & ( & $\begin{array}{l}\text { - Non hazardous } \\
\text { - Environmentally friendly disposal } \\
\text { - Low weight }\end{array}$ \\
\hline & $\begin{array}{l}\text { A15) 5th Filter: manufacturability of } \\
\text { parts/ components from selected materials, } \\
\text { and their environmental and economical } \\
\text { benefits }\end{array}$ & $\begin{array}{l}\text { - Promote a good product and process } \\
\text { performance } \\
\text { - Promote optimized and profitable } \\
\text { manufacture }\end{array}$ & $\begin{array}{l}\text { - Promote environmentally friendly } \\
\text { manufacture (ex: reduced raw- } \\
\text { materials loses, low hazardous } \\
\text { emissions, low infrastructure } \\
\text { demands) }\end{array}$ \\
\hline \multirow{2}{*}{ 矛 } & - A16) 6th Filter: materials use restrictions & $\begin{array}{l}\text { - Materials availability and timely } \\
\text { supply conditions } \\
\text { - Know-how and existing infrastructure } \\
\text { for materials use }\end{array}$ & $\begin{array}{l}\text { - Materials provision from local } \\
\text { suppliers }\end{array}$ \\
\hline & - A17) 7th Filter: detailed solution cost & - Project cost limit & - \\
\hline
\end{tabular}

- Detailing of activities:

A12) Verify materials receptivity and competitive differentiation, considering aesthetics, comfort and style issues, and environmental performance targets.

A13) Verify materials compliance to the aeronautical design secondary requirements: specifically for applications and materials compatibility.

A14)Evaluate environmental properties of materials related to toxicity, weight, disposal of scraps and residues generated during the manufacturing processes, recycling possibilities at the product end-of-life.

A15)Evaluate the ability to manufacture the parts/components from the selected materials and process, and the environmental and economical benefits of their use.

A16)Evaluate conditions to use pre-selected materials and process from experience, availability, materials supply logistics, possibility to develop local suppliers and infrastructure for product manufacturing.

A17)Detailed cost solution and verification according to the project budget. 
Appendix C: Product development guide to select materials for sustainable aircraft interiors in the design phases of Tests and Refinement, Manufacture, Launch, Sell and Product End-of-life.

\begin{tabular}{|c|c|c|c|}
\hline \multirow{2}{*}{$\begin{array}{l}\text { Product design } \\
\text { phase }\end{array}$} & \multirow[b]{2}{*}{ Activities } & \multicolumn{2}{|c|}{ Materials requirements: } \\
\hline & & $\begin{array}{c}\text { From aeronautical project and } \\
\text { clients }\end{array}$ & For sustainable design \\
\hline Tests and refinement & $\begin{array}{l}\text { - Manufacturing evaluation of } \\
\text { prototypes }\end{array}$ & $\begin{array}{l}\text { Promote product reliability } \\
\text { and sturdiness for aircraft use } \\
\text { conditions, desirable aesthetics and } \\
\text { comfort and certification }\end{array}$ & - \\
\hline Manufacture & - Pilot production & - Promote process capability & - \\
\hline Launch the product & $\begin{array}{l}\text { - Resources provision for selling } \\
\text { and pos-selling services }\end{array}$ & $\begin{array}{l}\text { - Have competitive appeal } \\
\text { - Promote easy maintenance and repair }\end{array}$ & $\begin{array}{l}\text { - Environmental appeal } \\
\text { - Easy refurbishing }\end{array}$ \\
\hline $\begin{array}{l}\text { Product selling and } \\
\text { follow-up }\end{array}$ & $\begin{array}{l}\text { - Monitoring product performance } \\
\text { - Monitoring promising } \\
\text { technologies of Materials and } \\
\text { processes } \\
\text { - Monitoring environmental } \\
\text { regulations }\end{array}$ & - Maintain competitiveness & $\begin{array}{l}\text { Maintain environmental } \\
\text { performance }\end{array}$ \\
\hline Product end-of-life & $\begin{array}{l}\text { - Encourage and facilitate reuse of } \\
\text { materials } \\
\text { - Monitoring recycling } \\
\text { technologies }\end{array}$ & - & $\begin{array}{l}\text { - Extend materials life cycle } \\
\text { - Environmentally friendly } \\
\text { disposal }\end{array}$ \\
\hline
\end{tabular}

